Article

\title{
An Exploration of Capitalism's Metabolism with Nature and its current Socio-Ecological Crisis
}

\author{
George Liodakis ${ }^{1, *}$
}

${ }^{1}$ Technical University of Crete, Department of Mineral Resources Engineering, 73100 Chania, Crete, Greece

E-Mails: liod@science.tuc.gr

* Author to whom correspondence should be addressed; Tel.: +30-28210-37317, liod@ science.tuc.gr

Received: 11 September 2013 / Accepted:11 November 2013 / Published: 11 November 2013

\begin{abstract}
Based on a dialectical-materialist methodology transcending the traditional Cartesian dualism, this assay sets out to explore the metabolic relationship between society and nature. Starting from an abstractive level concerning all societies, irrespective of the particular form of production, we proceed to more specifically examine this relationship under capitalism. In this case, the role of technology and the organic composition of capital are further explored. As suggested, technology is non-neutral and socially shaped, essentially constituting a purposive reorganization of nature fused with the imperatives of capitalist production. Analyzing the systemic necessity of a rising organic composition of capital and a secular decline in average profit rates, we explain the long-run and recently exacerbated over-accumulation crisis. As this crisis is inextricably intertwined with a deepening ecological crisis, we suggest a joint treatment within the currently exacerbated socio-ecological crisis. The strategy to face this crisis through capitalization of nature is shown to be counter-productive as it leads to a further ecological degradation, while increasing the organic composition of capital and the cost of production. While this exacerbated crisis implies a rising scarcity, a communist perspective seems to imply an increasing abundance. In this sense, we conclude with a brief exploration of the conditions for a rational reconstitution of the metabolism with nature within a communist perspective.
\end{abstract}


Keywords: capitalism; communism; ecological metabolism; technology; organic composition of capital; crisis.

\section{Introduction}

The exacerbated and multifaceted crisis facing capitalism and humanity on a planetary level raises a pressing need for further research regarding the causes and implications of crisis itself, the necessary measures and policies to tackle this crisis under the present institutional conditions, and also the sociopolitical processes or movements to supersede the capitalist mode of production (CMP) as the root cause of crisis.

Our main task here is to explore and explain the exacerbated socio-ecological crisis faced on a planetary level, considered within the evolving dialectical relationship between society and nature. This exploration focuses on the historical configuration of the interchange between society and nature, the specificity of this dialectical metabolism in capitalism, and the severing of this relationship manifested through crisis. Our present attempt will hopefully contribute in making a step beyond previous attempts to substantiate and explain this socio-ecological crisis [1], as well as in exploring the preconditions for the transcendence of this crisis through a supersession of the presently dominant capitalist mode of production.

In the second section of this essay we start with a general exploration of the relationship between society and nature, and proceed with a more specific analysis of this metabolic relation under capitalism. We also analyze the significance of the organic composition of capital and its organic relation to nature. In the third section we explore the role of technology in production and how technology, as a specific reorganization of nature in capitalism, contributes to a particular shaping of capitalism's metabolic relation with nature. We proceed in the following fourth section to more specifically explore the implications of a systemic increase in the organic composition of capital, which leads to a long-run over-accumulation tendency constituting a significant part of a systemically exacerbated socio-ecological crisis as the one currently facing global capitalism. We conclude in the fifth section by examining the prospects of socio-ecological crisis and the historical prospects beyond capitalism. The conditions of economic scarcity or abundance are more specifically analyzed both within capitalism, in relation to the current crisis facing capitalism, and within a transitional process and a communist perspective beyond capitalism.

\section{The society - nature metabolism and the organic composition of capital}

The relationship between people and nature is a relation stemming from the conscious efforts of human beings to utilize or appropriate nature in order to satisfy subsistence needs. This utilization, transformation or appropriation of nature is effected through human labor which constitutes a mediating process between humans and non-human (external) nature. This mediating activity implies an essentially dialectical interchange between people and nature, which Marx has characterized as a process of metabolism and, as he sufficiently elucidated, this process (human labor itself) implies not only a transformation of the external natural environment but also of human beings themselves [2]. The labor process, in general and independently of its specific social form, comprises three elementary 
factors: Work itself (a purposeful human activity), the subject [object] of that work, and the instruments of labor [5]. As Marx points out, there are two distinctive characteristics of humans and their productive activity, compared to all other animals. On the one hand, humans prefigure mentally and (consciously) plan before they proceed to a certain activity [6]. On the other hand, people use instruments of labor as a mediating means facilitating and extending human capacities to affect external nature beyond the reach of human bodily organs. In other words, "man [is] a tool-making animal" [7]. The instruments together with the subjects of labor (including the earth) constitute the means of labor (the means of production). It should also be noted that, as Marx indicates, to say that humanity "lives from nature" is to say that nature is "man's inorganic body" and that "nature is linked to itself, for man is a part of nature" [8].

In capitalism, the interchange between people and nature is specifically mediated by society. "The means of labour as such are then capital, and the land as such is landed property" [9]. The alienation of people from nature, or the alienation and estrangement of nature had already started with the establishment of private property in pre-capitalist class societies, but culminated with the dominant privatization of land and the means of production under capitalism. The traditional presentation of nature as an external reality is an outcome of exactly this alienation of nature. This alienation and the dispossession from direct producers of the means of production and subsistence has led in turn to a twin form of alienation, the alienation of wage labor from its product, and from other producers and society as a whole. It is in this sense that Marx points out that,

it is not the unity of living and active humanity with the natural, inorganic conditions of their metabolic exchange with nature, and hence their appropriation of nature, which requires explanation ... but rather the separation between these inorganic conditions of human existence and this active existence, a separation which is completely posited only in the relation of wage labor and capital. [10]

Utilizing natural forces and use values provided by nature, capitalism as a historically specific mode of production is more crucially based on the exploitation of wage labor within a process of production aiming at a maximal production of commodities and a maximum rate of profit and accumulation deriving from the extraction of surplus value through labor exploitation. Under capitalism, the process of production is both a labor and a valorization process [11]. The labor process is characterized by capitalist control and a proprietary relation to the product [12]. Under these specific social relations of production, nature's gift to the productive power of labor appears as productiveness of capital, and hence as nature's free gift to capital [13]. Capital takes the form of either constant capital (C), which includes all produced means of production, intermediate commodities and raw materials that transfer their value quantitatively unchanged through that labor process to the value of the final use values produced, or the form of variable capital (V) which is paid as wages to labor and can buy all the subsistence means necessary for the reproduction of the worker. This part of capital is variable in the sense that labor, apart from the necessary labor for the reproduction of labor power, also produces a surplus value through the surplus labor time worked in production.

Capital, then, as a specific social relation of production reflected on a self-expanding value, can be depicted on the following sequence, involving all three forms and the corresponding particular circuits 
of capital (money, productive, and merchant capital). An initial quantity of money capital (M) is expended to buy means of production $(\mathrm{C})$ and hire wage labor $(\mathrm{V})$ that are then combined through the labor process (LP) and use of a particular technology to produce a certain quantity of commodities (E) sold on the market for a greater quantity of money.

$$
\mathrm{M}=>(\mathrm{C}, \mathrm{V}) \ldots \mathrm{LP} \ldots \mathrm{E}\left(\mathrm{C}^{\prime}, \mathrm{V}^{\prime}, \mathrm{SV}\right)=>\mathrm{M}^{\prime} \quad\left(\mathrm{M}^{\prime}-\mathrm{M}>0\right)
$$

The labor process in general and also the capitalist labor process are mediated by certain tools or instruments of labor reflecting a particular technology. Moving from the simple case where a tool is mediating and facilitating the relation between human labor and the external nature (as a subject of labor) to more complex circumstances, as is commonly the case with the development of production and the productive forces under capitalism, we can realize that "[i]n a wider sense we may include among the instruments of labour ... all such objects as are necessary for carrying on the labour process" [14]. As Marx more specifically points out,

Instruments of labour not only supply a standard of the degree of development to which human labour has attained, but they are also indicators of the social conditions under which that labour is carried on. [15]

In a similar sense and as regards the technology associated with these instruments (and methods) of production, it is also stated that

Technology discloses man's mode of dealing with Nature, the process of production by which he sustains his life, and thereby also lays bare the mode of formation of his social relations, and of the mental conceptions that flow from them. [16]

Here, one can observe that Marx is clearly anticipating an interesting theoretical trend during recent decades concerning the social shaping of technology $[11,17,18,19,20,21]$. This social shaping of technology does not of course imply an underestimation of the fact that, once a particular technology is crystallized, it dialectically and significantly impacts on the further restructuring and reorganization of social production.

The social shaping of technology has significant implications for the particular proportion in which constant capital is related to variable capital in production. The imperative of capitalist profitability and cost minimization, along with the inherently competitive character of capitalist production, imply an increasing mechanization (and automation) of production which allows an increase in the productivity and discipline of labor, as well as increasing throughput of natural resources, namely the transformation of a maximum amount of natural use values into final use values (commodities). Thus, there is a tendency for the portion of constant capital (instruments and materials of labor, C) to increase more rapidly than the portion concerning variable capital (wage expenses, V), and for the composition of capital to change accordingly. Following Marx,

By composition of capital we mean ... the proportion of its active and passive components, i.e., of variable and constant capital. ... the technical composition of capital [the ratio $\mathrm{C} / \mathrm{V}$ in physical terms] ... is the real basis of its organic composition. ... The value composition of 
capital, inasmuch as it is determined by, and reflects, its technical composition, is called the organic composition of capital. [22]

Although we return to this conception of the organic composition of capital (OCC) below, it should be noted here that Marx clearly implies that temporary or conjunctural changes in the values and hence prices of $\mathrm{C}$ and $\mathrm{V}$ should be disregarded in the determination of the OCC. The latter is the value composition of capital which reflects the long-term crystallization of a technical composition which is implicitly assumed to be profitable, and hence functional for capital, and by extension encompasses a particular functional (organic) relation with nature.

The social shaping of technology, within a class divided and exploitative society such as capitalism, also implies that, contrary to mainstream thinking, but also a certain part of traditional Marxism, technology and the social forces of production more generally cannot be socially neutral and beneficial for all $[18,21]$. It is worth here citing Marx at length to show that he was quite clear on this.

In agriculture as in manufacture, the transformation of production under the sway of capital, means, at the same time, the martyrdom of the producer; the instrument of labour becomes the means of enslaving, exploiting, and impoverishing the labourer; the social combination and organization of labour-processes is turned into an organized mode of crushing out the workman's individual vitality, freedom, and independence. ... all progress in capitalist agriculture is a progress in the art, not only of robbing the labourer, but of robbing the soil; all progress in increasing the fertility of the soil for a given time, is a progress towards ruining the lasting sources of that fertility. The more a country starts its development on the foundation of modern industry ... the more rapid is this process of destruction. Capitalist production, therefore, develops technology, and the combining together of various processes into a social whole, only by sapping in original sources of all wealth - the soil and the labourer. [23]

\section{Technology as a social reorganization of nature}

In a first attempt to define technology, it could be said that it is the sum total of the specifically and purposively constructed means and instruments of production, of the methods of production and the accumulated relevant knowledge, which are all specifically articulated and harnessed by human labor in order to produce a certain product or effect (work). In a broader sense, it is plausibly argued that the labor process itself can be conceptualized as

the movement of nature infused with human purpose and harnessed to the satisfaction of human needs. Technology, rather than simply a tool used to humanize nature, is itself a form of nature shaped to meet human needs, distinct from the other forms of nature in the labour process by virtue of its role in mediating the relation between labour and raw material. In a word, technology is humanized nature. [24]

It is conceivable indeed that human beings and their labor power are part of nature insofar as they are depending on nature for their subsistence and on the consumption of organic food (animals and plants), while animals subsist on plant (or other animal) foods, and inorganic matter mainly provides the food for plants. The tools and instruments of labor, as a particular expression of technology, are also 
constituted through past labor and an objectification of nature (energy and materials), while other aspects of technology are essentially based on natural forces and processes. Technology, then, is "a form of nature shaped to meet human needs", because, as Marx points out,

Nature builds no machines, no locomotives, railways, electric telegraphs, self-acting mules, etc. These are products of human industry; natural material transformed into organs of the human will over nature, or of human participation in nature. They are organs of the human brain, created by the human hand; the power of knowledge, objectified. [25]

Here we can clearly see the crucial role played by a more or less conscious and purposive human intervention in nature. But this transformative intervention of humans is not unlimited. From a materialist standpoint, we should realize that it is constrained by the already crystallized technology and the existing conditions of the natural world, as well as by natural laws. "What is needed", in this methodological sense, "is a nondeterministic materialism and ecological humanism that recognize the dialectical linkages between humanity and nature, between human consciousness and the natural world" [26].

In an attempt to conceptualize technology more specifically, I would suggest that a clarification of the relationship between technology and organization, or social organization in particular, is crucial. It is commonly conceived that technology and organization constitute two independent entities, though it might be recognized that technology may affect social organization (of production or society at large) and organization may also affect the development of technology. As some authors point out, each capitalist labor process (and this might apply in general) is characterized by a specific organization of labor and a particular technology of production [27]. Technology is also commonly considered as distinct from nature and as a means to intervene into nature. However, if we move from the simple case of a particular tool or instrument to more complex technological systems, we realize that social organization is necessarily a constituent element of these systems, and each and every form of social organization encompasses and is based upon particular types of technology. Technology and organization are dialectically and inextricably related insofar as they fuse together as a particular form of nature. All instruments and methods of production, whether simple or complex, are essentially constituted by various combinations of natural materials, different forms of nature and/or different sequences of natural forces. Along the lines of the analysis provided above, it can then be argued that technology itself is a socially specific reorganization (reordering) of nature. It essentially concerns a particular reorganization within and between inorganic and organic nature, and of the relationship between people and non-human nature. "There are, of course, valid distinctions between people, artefacts, and unmediated nature. But boundaries between these have to be seen as shifting - or as ones which can be crossed back and forth, i.e., transitive". [28]. Within a historically specific mode of production, the prevailing social relations of production do not only encompass a particular type of property relations (the relation to the means of production), but more deeply and specifically determine technology as a relational reorganization within nature.

With capitalism, nature becomes for the first time an object and a matter of utility. As Marx puts it, 
For the first time, nature becomes purely an object for humankind, purely a matter of utility; ceases to be recognized as a power for itself; and the theoretical discovery of its autonomous laws appears merely as a ruse so as to subjugate it under human needs, whether an object of consumption or as a means of production. [29]

With the coming of the machine more specifically, "the forces of nature are themselves infused with human purpose" and "the instruments of production themselves come to approximate a force of nature." Arguably, "it is in this sense that Marx suggests that, rather than merely "modified natural things' standing between human beings and an object, industrial technologies are themselves a force of nature, a natural process transformed into an industrial process" [30]. As is further noted, "The unique humanization of nature constituted by machine systems emerges historically in the form of fixed capital, as private property standing in an alienated relation to living labour" [31]. In this case, the social intentionality infused in technology and the transformation of nature is strictly determined by the imperative of capitalist profitability. From the other side, natural conditions, along with class struggles, partly determine the specific form of technology and the structure of the social relations of production [32].

It is because of this tight dialectical interrelation between society and nature that it is misleading, as $\mathrm{J}$. Moore argues [33], to consider the impact of capitalism on the ecosystem as an external reality. It is rather more appropriate to conceive of capitalism in nature and a specifically capitalist ecology. Within this context, the specifically capitalist shaping of technology, in the broad sense outlined above as a reorganization of nature, has certainly significant implications on the metabolism between society and nature. It implies a specifically capitalist metabolism with nature.

It should be stressed that the social shaping of technology under capitalism implies a capital-intensive technology and, as already noted, an increasing mechanization of production which tends to systematically increase the OCC. The increasing accumulation of capital in its fixed form constitutes an objectification (crystallization) of nature, including past alienated labor and natural resources, transformed into private property. Insofar as capital can freely appropriate nature, this objectification of nature will continue unrestrictedly. However, potential social restrictions and increasing ecological limitations in the free appropriation of nature will tend to induce an increasing capitalization (and instrumentalization) of nature which, as analyzed further below, encompasses the production of new nature(s) and an increasing subsumption of nature under capital. Through technology, we are therefore led to a specific configuration of the metabolism with nature. Referring to biotechnology in particular, E. Yoxen points out that, its goal is to sustain the circulation and accumulation of capital by regulating the deskilling and displacement of workers, inhibiting resistance, and offering a new set of products and production processes. Thus, "[1]ife becomes a productive force, playing a growing role in reconstituting the social relations of a new capitalist order" [34].

This capitalist shaping of technology has profound implications for both wage labor and natural resources. While mainstream theory conflates profitability with economic (and social) efficiency, profitable capitalist technologies often lead to an inefficient use and squandering of both labor and nature, due to increasing intensification of labor, free appropriation and depletion of natural resources, and negative environmental externalities. This systemic bias in the development of technology may 
imply: (1) an increasing restriction of autonomous labor and the subordination of labor under capital as abstract alienated labor, (2) an intensification of labor exploitation, (3) a differential class appropriation of nature, and (4) a systemic degradation or disruption of the life sustaining ecosystem. As these implications from the development and use of technology involve intense social and class conflicts, they also fuel class struggles with significant repercussions for further technological developments and the specific configuration of the capital - nature metabolism [32].

As it becomes clear from the above, the approach developed here, (a) transcends the Cartesian society/nature dualism, while elucidating the dialectic relationship between organic and inorganic or human and non-human nature, (b) transcends technological determinism by stressing the social shaping of technology, (c) substantiates the specificity of capitalist technology and its socially nonneutral character, (d) overcomes the arbitrary technology/ organization divide by stressing the continuity between nature and society and conceiving technology as a specific reorganization of nature, and (e) substantiates the specific character of the society - nature metabolism under capitalism.

\section{The rising OCC, over-accumulation of capital and the exacerbated socio-ecological crisis}

Profitability is a central imperative of the CMP and the rate of profit a crucial indicator reflecting the conditions of reproduction and accumulation of capital. Following a standard Marxian analysis, we can here define the average rate of profit ( $p$ ) as the ratio of the total surplus value extracted (S) in relation to the total capital invested as either constant capital (C) or variable capital (V). Dividing both nominator and denominator of this ratio by $\mathrm{V}$, this relation is transformed as follows:

$$
\mathrm{p}=\mathrm{S} /(\mathrm{C}+\mathrm{V})=\mathrm{s}^{\prime} /\left(\mathrm{c}^{\prime}+1\right)
$$

Here, $s^{\prime}=\mathrm{S} / \mathrm{V}$ stands for the rate of surplus value (or the degree of labor exploitation) and $\mathrm{c}^{\prime}=\mathrm{C} / \mathrm{V}$ stands for the organic composition of capital (OCC).

As already pointed out, there is an inherent imperative in the CMP leading to increasing mechanization of production and a rising OCC. If we assume that the rate of exploitation remains unchanged, this implies a tendency towards a falling rate of profit (TFRP), as it can be seen from the relation (1) above. This is the main tendency ("the law as such"), according to Marx and the relevant contemporary Marxist analysis [35,36,37,38]. This law (the main tendency) may be counteracted by a number of other (counteracting) tendencies, which may tend to either decrease the OCC or increase the rate of exploitation ( $\left.s^{\prime}\right)$, and hence increase the rate of profit. If these counteracting tendencies are not strong enough, the rising OCC and the TRPF will lead to an over-accumulation crisis. This is a powerful interpretation of the recurrent crises of capitalism and the current crisis (and recession) of global capitalism.

As the OCC plays an apparently crucial role in this analysis, it is necessary to elaborate further on its systemic increase. Starting from the maximum profitability imperative of the CMP, we can realize that this goal requires cost minimization which can be achieved, either through mechanization and automation of production, or through a maximum "free appropriation of nature" external to capitalist 
reproduction and an extensive externalization and a cost-shifting from private capital to society. This implies a continuous increase in the productivity of labor which "consists precisely in that the share of living labour is reduced while that of past labour is increased, but in such a way that the total quantity of labour incorporated in that commodity declines" [39]. Increasing labor productivity implies that a certain amount of labor can set in motion or transform an increasing amount of natural use values (raw materials and energy), while such a maximum transformation (or throughput) of natural resources is a precondition for the materialization of a maximum quantity of exchange values (commodities). Both, the mechanization of production, the consequent increase in labor productivity, and the increasing potential of a material throughput imply a systemic increase in the OCC. As Marx points out, "[w]ith the exception of extractive industries ... all branches of industry manipulate raw material ... already products of labour" [40]. To put it differently,

The beginning of one labour process already assumes in its means of production the end points of all sorts of other labour processes, with the use values which those labour processes yield up. All, however, are sclerosed living labour, all are resolutions of social and economic forces, all are snapshots of the history of class struggle. [41]

This means that, as the amount of constant capital (C) tends to increase, the OCC will also accordingly increase.

Following Marx's terminology for the composition of capital, we can here interpret the organic composition of capital in a dual sense implying a particular configuration of production that, on the one hand serves the profitability of capital and the reproduction/development of the capitalist relations of production, and on the other ensures this reproduction on the basis of an organic relation to the rest of nature. This organic relation of capital to nature enables a maximum appropriation of nature and in this sense the OCC represents a particular interface between capitalist production and nature. As it becomes clear, this organic relation is placed within a specifically capitalist ecology and a specific metabolism with nature.

Concerning the secular increase in the OCC itself, it should be noted that several commentators have in the past argued that the increasing productivity of labor implies a cheapening of constant capital (C) and this might imply a reduction of the OCC and hence a counteracting influence on the TRPF. It could be argued, however, that the increasing labor productivity may also reduce the cost of reproduction of labor power and hence the value of variable capital (V). Taking also into account that the expanding accumulation of capital implies an increasing bulk of constant capital (means of production, energy and raw materials), we can conclude that the argument regarding the cheapening of $\mathrm{C}$ is not sufficiently valid. There are also two recent trends in the literature which might have some relevance for the historical trends of $\mathrm{C}$ and the OCC. One of them concerns a presumable tendency towards immaterial labor and immaterial production, associated with some autonomist Marxist ("postworkerist") approaches, while the other relates to a more empirical argument developed within the mainstream literature pointing to a presumably increasing de-materialization of production.

As pointed out, however, even the apparently immaterial forms of production (such as services or knowledge production) and the labor involved in this production are encompassing significant material 
premises $[42,43,44]$. Although the actual increase of the technical and organic composition of capital is an empirical question, it might appear that some modern technologies (e.g. information technologies) do not require so much fixed capital and hence imply a limited increase in the composition of capital. This increase, however, may become unquestionable, if we properly consider the broader category of "passive" or "constant" capital (including also software and all forms of past, crystallized labor) compared to living labor. In clear contrast to the implications of a putative immaterial production, referring to the fixed component of constant capital, Marx notes:

The development of fixed capital indicates to what degree general social knowledge has become a direct force of production, and to what degree, hence, the conditions of the process of social file itself have come under the control of the general intellect and been transformed in accordance with it. To what degree the powers of social production have been produced, not only in the form of knowledge, but also as immediate organs of social practice, of the real life process. [45]

The so-called "de-materialization" hypothesis is expressed by a putative decline in the materials and energy requirements necessary for a certain amount of production (GDP). De-materialization is usually conceived as "a joint concept including both eco-efficiency and substitution and refers to a decoupling of economic growth from resource consumption and negative environmental impacts" [46]. However, as argued in greater detail elsewhere, there are good, both theoretical and empirical reasons to dispute this hypothesis $[1,46,47,48,49,50]$.

Apart from this refutation of de-materialization arguments, there are more important reasons to assume that the increasing depletion and degradation of natural resources and the environment lead to an increasing cost of production and an increase in the value of constant capital, which most likely implies a rising OCC. Encountering such difficulties and an increasing exhaustion of natural reserves, capital has long ago, but more intensively during recent decades, embarked on a great scale attempt to produce new nature(s) and extensively capitalize nature $[17,18,51,52,53]$. We will consider here this capitalization of nature as an expanding and deepening process of subsumption of nature under capital, which encompasses the production of new nature(s), the intentional harnessing of technology to reorganize nature according to the needs of capital, bioprospecting and biopiracy, and the conservation or enclosure of nature as a condition of capitalist production. The intention of capitalist agents is to substitute or more abundantly reproduce the conditions for the accumulation of capital, reduce the natural uncertainties and ecological risks facing the accumulation process, and reduce production costs to enhance the profitability of capital [54]. But although the strategy to capitalize nature is partly effective in overcoming or displacing natural limits, it essentially constitutes a curse against these ecological limits and is rather shortsighted and self-defeating as it tends, particularly during recent decades, to cumulatively exacerbate the socio-ecological crisis facing capitalism. As the requirements of a fast growing capitalism tend to exhaust natural reserves and the freely appropriated nature, and the expanding capitalization of nature tends to restrict this potential of a free appropriation, these processes together with the rising cost of this capitalization itself imply a rapid increase in the cost of capitalist production, which undermines the raison d'être of the CMP itself. It is for these reasons that "capital's first preference is to appropriate nature, rather than produce it through the circuit of capital" [55]. 
However, insofar as this free appropriation of nature is systemically restricted, the increasing capitalization of nature "creates a world-historical situation of rising production costs stemming from the degradation of the conditions of production" [56].

The implication of the argument above is that, instead of a "de-materialization" process counteracting the TRPF and relaxing the environmental tensions of capitalist growth, we have an increasing capitalization of nature which tends to increase both ecological degradation and the cost of production. This capitalization of nature, by intensifying the cycle of production, exhausting natural forces and reserves, and violating ecological relations and balances, leads to manifold ruptures and rifts with the rest of nature. At the same time, it raises the cost of production in general and of constant capital in particular, while offering an adequate explanation of the more rapid increase of constant capital compared to living labor, and hence of the systemic increase of the OCC. This secular increase of the OCC, encountering apparently no limits, is also empirically confirmed in most countries, while the potential increase in the rate of labor exploitation as a counteracting tendency reducing the TRPF faces definite bio-political limits. As a result, the TRPF will dominate and, despite all counteracting tendencies which are often mediated through the state, a falling profitability will be manifested, sooner or later, as an aggravated over-accumulation crisis. The more specific expressions of this crisis include a rapid decline in production and investment, an expansion of unemployment, and a destruction of a considerable part of the accumulated means and forces of production, which is ironically conceived as a condition for the short-term recovery of the capitalist economy [57]. This over-accumulation tendency has again been confirmed in most countries, but also on a global level, within a rapidly globalizing capitalism $[58,59,60,61]$.

These long-run (over-accumulation and crisis) tendencies of capitalism, may be indicative of the historical limits of capitalism, but should not be interpreted in a mechanistic way implying an imminent collapse of capitalism. In fact, the sustainability and viability of capitalism is also mediated by a number of other factors (including ideology and the state) and depends on a broader and far more complex dialectical process. It would be misleading therefore to focus on the over-accumulation crisis alone.

As argued elsewhere, this economic form of the crisis facing world capitalism is so intimately and dialectically intertwined with a rapidly exacerbated ecological crisis that we can legitimately speak of a more general socio-ecological crisis [1]. Highlighting this crisis, one could stress the following three as its main manifestations: (1) the profitability and accumulation crisis culminating with the recent severe crisis and worldwide recession, (2) an exacerbated ecological crisis as a growing disjuncture and rupture in the specifically capitalist interchange between society and nature, and (3) a deep and protracted crisis in all forms and institutions of social organization, a disruptive cultural degradation, and as a snapshot of all these a crisis regarding the preconditions of human development.

The ecological form of the crisis pointed out above may be attributed, firstly, to a systemic transcendence of ecological limits. Although these limits, in their strict Malthusian sense, can be displaced and relativized through a technological reorganization and capitalization of nature, they cannot be effaced. Secondly, and as a result of capitalist growth, this crisis may come about through a violent and destructive disruption of natural/organic relations within the ecosystem, and extensive 
ruptures or imbalances in natural cycles and eco-regulating processes, which may significantly upset the normal reproduction of the ecosystem. The implications of this crisis are important. On the one hand, by increasing scarcity in the provision of cheap food, energy and materials, and by failing to provide a stable and safe ecological environment, it puts increasingly severe limits to capitalist accumulation [50]. On the other hand, by destroying the conditions for the reproduction of the ecosystem or leading to a serious degradation in the capitalist metabolism with nature, it also undermines the conditions necessary to sustain the prevailing mode of production and the civilization developed on this basis.

Although capitalism has so far shown a remarkable resilience and capacity to overcome socioecological crises, by exploiting new technological or institutional innovations, shifting to new sources of energy and raw materials, or moving to new frontiers of accumulation [33,53], the currently highly exacerbated socio-ecological crisis seems extremely difficult to overcome. Our analysis regarding the systemic exacerbation of this crisis indicates that it is rather more likely that capitalism has exhausted most of its historical limits. And although there is some literature which attempts to identify some long cycles (long waves) of capitalist accumulation and correlate these cycles with major technological or institutional innovations, there are serious reservations whether such regular long cycles can actually be confirmed, and whether some new technological or institutional innovations could provide a new deus ex machina to ensure a new wave of accumulation and a perpetual reproduction of capitalism beyond any historical limits $[33,58,60]$.

But rather than speculating on any prospective innovations and capitalist accumulation, it may be more fruitful to focus attention on the class struggles and social mobilizations that might be activated by the increasingly miserable economic conditions facing the working social majority, the rapid degradation of ecological conditions, and the equally miserable conditions for human development. A more specific analysis of such struggles and social mobilizations is beyond the scope of this article. It may be more relevant, however, to briefly refer to the conditions and implications of relative scarcity or abundance associated with the dominant mode of production and the exacerbated crisis, or an alternative social organization.

Although capitalism has promised an abundant production of goods to increase social welfare, by systematically ignoring ecological limits, capitalist development by itself and the socio-ecological crisis exacerbated on a global level during recent decades actually imply a growing scarcity in the productive resources available and the use values produced to satisfy social needs. Amidst an apparent abundance of commodities produced, there seems to be a growing scarcity of use values available to satisfy the real needs of the great social majority, while the growing scarcity in productive resources puts important constraints in the development of capital itself. This increasing scarcity is further intensified by recent institutional changes regarding the protection of intellectual property rights (IPRs) and the enclosure of knowledge or various natural and biological resources, which clearly reflect the need of capital to appropriate and even more intensively valorize both social and natural resources. This growing scarcity is an essential reflection of the deepening crisis in the society - nature metabolism and the exacerbated socio-ecological crisis. But equally important aspects of this crisis concern a qualitative degradation or disruptions in the relations among various parts of nature or 
between nature and capital or society at large. As already noted, this deepening crisis of the metabolic relationship between capital and nature raises great difficulties and important constraints for the sustainable reproduction and accumulation of capital. This, in turn, creates the preconditions and opens a prospect for the historical supersession of capitalism. We need, therefore, to more specifically examine this perspective, at least in some particular respects.

\section{The current socio-ecological crisis and the prospects of superseding capitalism}

The currently exacerbated socio-ecological crisis and the crisis in the metabolic relationship between capital and nature, more specifically, tend to undermine the conditions for a sustainable development and a continual process of capitalist accumulation. And although one could not exclude the possibility of some major technological innovations and/or institutional restructuring that might allow a long-term accumulation of capital, the current crisis undoubtedly and in many respects raises a prospect for the transition beyond capitalism. Focusing on the material preconditions of such a transition, Marx is particularly eloquent in the Grundrisse, where he highlights the process of industrial development, along which, the direct labor in production is gradually replaced by the application of science and the productiveness of social labor, the labor time and exchange value as a measure of social wealth break down, and the appropriation of surplus labor ceases to be the main goal of production. Instead, social labor becomes the main source of social wealth, allowing the development of rich individualities within an associated production [62].

Along the lines of such a projection, it has been more specifically argued elsewhere that a reconstitution of the conditions for a truly sustainable development and a rational interchange and organic metabolism with nature can be realized only within a communist perspective $[1,63]$. This perspective would also generate the necessary conditions enhancing a relative abundance of productive resources and social wealth, without fully eradicating all natural scarcities [64].

Within the prevailing and historically specific mode of production, and the associated and specifically shaped metabolism within nature, it is therefore important to examine these conditions of a relative scarcity or abundance, as they are largely the outcome of the prevailing social relations and, at the same time, a precondition or a constraint for the further development of this mode of production. In this sense, it may be pertinent to explore these conditions of a growing scarcity or abundance as an essential aspect and a constituent element of the dynamic transformation process from capitalism to communism.

Scarcity or abundance should not be interpreted, as is often done by mainstream theory, but also by some Marxist authors, as a naturalistic conception and comparison of a relative availability of a certain good or resource and the extant need (or demand) for it. It would be rather misleading to consider that natural conditions by themselves, or the development of technology and the productive forces, would decisively determine the relative scarcity or abundance of a certain good or resource. Social conditions and relations play an even more crucial determinant role. It may be sufficient here to consider the radical implications towards enhancing an economic and social abundance ensuing from social changes such as the dis-alienation, within a communist perspective, of natural resources (nature) and the productive forces, the unfettering of these forces and social knowledge through cooperation, the 
abolition of private property and commodity production, and hence the appendage of production on social need rather than private profit, the expansion of the production and consumption of common goods, the expansion of free time and the development of a relevant culture, and a collective and ecologically minded management of resources and social needs. The question which then arises is whether the contradictory relation between a relative abundance and a growing scarcity creates a historically limiting condition for capitalism, whether this condition contributes to a historical transition from capitalism to communism, and whether a growing abundance would be a selfreinforcing factor within such a communist perspective.

Examining the case of capitalism, we should recognize on the one hand that the rapid productivity increase along with the growth of capitalist production tend to generate a relative abundance in the form of commodities produced, and hence to a potential decline of scarcity. Economic or technological substitution may also potentially reduce scarcities in productive resources and final products, but this substitution is limited and may come forth only at an increasing cost [49]. On the other hand, we should take into account, firstly, that capitalist growth entails a growing depletion of natural resources and hence an increasing scarcity [50]. Referring to the danger of depletion of non-renewable resources in particular, E. Mandel points out that "[s]aturation of demand, of consumption, is not only possible; it is absolutely necessary for the survival of humanity. That is one of the reasons why it has become a life-and-death question to eliminate a system which institutionalizes scarcity by stimulating demand for ever-changing goods" [65]. We should, secondly, take into account that an increasing (and often artificial) scarcity is systemically imposed as a precondition of commodity production and a condition for the protection of private property rights (including IPRs), and hence a condition for the appropriation of monopolistic profits or rents. It seems, therefore, that the relative abundance of commodities produced is overshadowed by a systemic increase of scarcity concerning both productive resources, biodiversity, and use values satisfying social needs. Even a relative abundance of commodities may be meaningless for the working social majority insofar as income constraints may limit access to these commodities, implying thus a real and increasing scarcity.

Under communist conditions, there are several reasons implying a reduction of scarcity and a growing abundance. Among these reasons we should include: (a) common social property, collective production, and social cooperation, which unleash the development of the productive forces and labor productivity without impinging upon a sustainable reproduction of the ecosystem, (b) the production and availability of common goods which are accessible to all (abundance precludes the possibility of commodity production and the resulting scarcity), and (c) a non-growth economy aligned to social needs, which does not need to imply a depletion of natural resources and an increasing scarcity.

Presently, the increasing scarcity may induce an individualistic behavior for survival and, in this sense, constitute an impediment to collective action as a precondition for a transition to a communist reorganization of society. On the other hand, an increasing abundance, which may be an outcome of scientific/technological developments, a rising productivity of labor, and a growing socialization of production (including the production of knowledge), places increasing limits to a further commodification/capitalization of production, while enabling the dominated and exploited classes in 
waging a more effective struggle towards an abundance enhancing and self-reinforcing expansion of commons production, and a more comprehensive transformation towards communism.

We may conclude from above that the growing scarcity under present day capitalism is both an outcome and a constituent element of a specifically capitalist metabolism between society and nature, which inexorably leads to an increasingly aggravated socio-ecological crisis. As this increasing scarcity and the rapid economic and environmental degradation dramatically limit the prospects of a dissent human development, it becomes increasingly apparent that an essential overcoming of this degradation and crisis presupposes a historical supersession of capitalism. But such supersession could not simply and mechanistically come about through a rising scarcity or an automatic collapse of capitalism. It rather requires a conscious long term revolutionary struggle to achieve a real emancipation of both human beings and nature, and thus radically and more rationally reconstitute the metabolic process between society and nature.

\section{Conflict of Interest}

The author declares no conflict of interest.

\section{References and Notes}

1. Liodakis, G. Considering (Economic and Ecological) Crisis from a Communist Perspective. Perspectives on Global Development and Technology 2013, 12(1-2), 194-218.

2. Marx, K. Capital I; International Publishers: New York, USA, 1967; pp.177, 505. See also [3], 104106; [4], ch.5.

3. Dickens, P. Reconstructing Nature: Alienation, emancipation and the division of labour; Routledge: London, UK, 1996.

4. Foster, J.B. Marx's Ecology: Materialism and Nature; Monthly Review Press: New York, USA, 2000.

5. Marx, K. Capital I; International Publishers: New York, USA, 1967; p. 178-184.

6. Marx, K. Capital I; International Publishers: New York, USA, 1967; p. 178.

7. Marx, K. Capital I; International Publishers: New York, USA, 1967; p. 179.

8. Cited in Foster, J.B. and Burkett, P. The Dialectic of Organic / Inorganic Relations: Marx and the Hegelian Philosophy of Nature. Organization \& Environment 2000, 13(4), 403-425 (p. 412).

9. Marx, K. Capital III; International Publishers: New York, USA, 1967; p. 825.

10. Marx, K. Grundrisse; Vintage Books: New York, USA, 1973; p. 489.

11. MacKenzie, D. Marx and the Machine. Technology and Culture 1984, 25, 473-502.

12. Marx, K. Capital I; International Publishers: New York, USA, 1967; p. 184-185.

13. Marx, K. Capital III; International Publishers: New York, USA, 1967; p. 745.

14. Marx, K. Capital I; International Publishers: New York, USA, 1967; p. 180.

15. Marx, K. Capital I; International Publishers: New York, USA, 1967; p. 180.

16. Marx, K. Capital I; International Publishers: New York, USA, 1967; p. 372.

17. Yoxen, E. Life as a Productive Force: Capitalising the Science and Technology of Molecular Biology. In Levidow, L. and Young, B. (eds) Science, Technology and the Labour Process: Marxist Studies, volume I; CSE Books: London, UK, 1981; pp.66-122. 
18. Young, B. Is Nature a Labour Process? In Levidow, L. and Young, B. (eds) Science, Technology and the Labour Process: Marxist Studies, volume II; Free Association Books: London, UK, 1985; pp.206-232

19. MacKennzie, D. and Wajcman, J. The Social Shaping of Technology; Open University Press: Philadelphia, USA, 1985.

20. Noble, D. Progress Without People: New Technology, Unemployment, and the Message of Resistance; Between the lines: Toronto, CA, 1995.

21. Tanuro, D. Marxism, Energy, and Ecology: The Moment of Truth. Capital Nature Socialism 2010, 21(4), 89-101.

22. Marx, K. Capital III; International Publishers: New York, USA, 1967; p. 145-146.

23. Marx, K. Capital I; International Publishers: New York, USA, 1967; p. 506-507.

24. Fish, K. Machine Systems and the Unique Nature of Industrial Capitalism. Critical Sociology 2010, 37(1), 125-143 (p.130).

25. Marx, K. Grundrisse; Vintage Books: New York, USA, 1973; p. 706.

26. Cited in Foster, J.B. and Burkett, P. The Dialectic of Organic / Inorganic Relations: Marx and the Hegelian Philosophy of Nature. Organization \& Environment 2000, 13(4), p. 421.

27. Bowles, S., Edwards, R. and Roosevelt, F. Understanding Capitalism, Third Edition; Oxford University Press: New York, USA, 2005; ch.13.

28. Young, B. Is Nature a Labour Process? In Levidow, L. and Young, B. (eds) Science, Technology and the Labour Process: Marxist Studies, volume II; Free Association Books: London, UK, 1985; p. 217.

29. Marx, K. Grundrisse; Vintage Books: New York, USA, 1973; p. 409-410.

30. Fish, K. Machine Systems and the Unique Nature of Industrial Capitalism. Critical Sociology 2010, 37(1), p. 135.

31. Fish, K. Machine Systems and the Unique Nature of Industrial Capitalism. Critical Sociology 2010, 37(1), p. 137.

32. Keefer, T. Fossil Fuels, Capitalism, And Class Struggle. The Commoner 2009, No.13, 15-21.

33. Moore, J.W. Transcending the Metabolic Rift: A Theory of Crises in the Capitalist World-Ecology. Journal of Peasant Studies 2011, 38(1), 1-46; Moore, J.W. Ecology, Capital, and the Nature of our Times: Accumulation \& Crisis in the Capitalist World-Ecology. Journal of World-Systems Research 2011, 17(1), 108-147.

34. Yoxen, E. Life as a Productive Force: Capitalising the Science and Technology of Molecular Biology. In Levidow, L. and Young, B. (eds) Science, Technology and the Labour Process: Marxist Studies, volume I; CSE Books: London, UK, 1981; p. 112; See also [3], 113-116.

35. Marx, K. Capital III; International Publishers: New York, USA, 1967; ch.XIII-XV.

36. Moseley, F. The Rate of Profit and Economic Stagnation in the US Economy. Historical Materialism 1997, 1, 161-74.

37. Kliman, A. The Persistent Fall in Profitability Underlying the Current Crisis: New Temporalist Evidence; Marxist Humanist Institute: New York, USA, 2010.

38. Carchedi, G. Behind the Crisis: Marx's Dialectics of Value and Knowledge; Historical Materialism 26, Leiden: Brill, 2011.

39. Marx, K. Capital III; International Publishers: New York, USA, 1967; p. 260-261.

40. Marx, K. Capital I; International Publishers: New York, USA, 1967; p. 181. 
41. Young, B. Is Nature a Labour Process? In Levidow, L. and Young, B. (eds) Science, Technology and the Labour Process: Marxist Studies, volume II; Free Association Books: London, UK, 1985; p. 216.

42. Carchedi, G. Behind the Crisis: Marx's Dialectics of Value and Knowledge; Historical Materialism 26, Leiden: Brill, 2011; p. 60-85.

43. Lessa, S. The "immaterial labor": Negri, Lazzarato and Harndt. UTOPIA 2006, no.71.

44. Starosta, G. Cognitive Commodities and the Value-Form. Science \& Society 2012, 76(3), 365-392.

45. Marx, K. Grundrisse; Vintage Books: New York, USA, 1973; p. 706.

46. Næss, P. and Høyer, G. The Emperor's Green Clothes: Growth, Decoupling, and Capitalism. Capitalism Nature Socialism 2009, 20(3), 74-95 (pp. 74-75).

47. Unruh, G. C. Understanding carbon lock-in. Energy Policy 2000, 28(12), 817-830.

48. Trainer, T. The "de-materialisation" myth. Technology in Society 2001, 23(4), 505-514.

49. Sulston, J. Sir (Chair of Working Group). People and the Planet, report of The Royal Society, 2012 (http://royalsociety.org).

50. Magdoff, F. Global Resource Depletion: Is Population the Problem? Monthly Review 2013, 64(8), $13-28$

51. O'Connor, M. The System of Capitalized Nature. Capitalism Nature Socialism 1992, 3(3), 94-99.

52. Smith, N. Nature as Accumulation Strategy. In The Socialist Register 2007. Coming to Terms with Nature, L. Panitch and C. Leys (eds); Merlin Press: London, UK, 2006; pp.16-36.

53. Moore, J.W. The End of the Road? Agricultural Revolutions in the Capitalist World-Ecology, 1450-2010. Journal of Agrarian Change 2010, 10(3), 389-413.

54. Sulston, J. Sir (Chair of Working Group). People and the Planet, report of The Royal Society, 2012; p. 72-82.

55. Moore, J.W. The End of the Road? Agricultural Revolutions in the Capitalist World-Ecology, 1450-2010. Journal of Agrarian Change 2010, 10(3); p. 400.

56. Moore, J.W. The End of the Road? Agricultural Revolutions in the Capitalist World-Ecology, 1450-2010. Journal of Agrarian Change 2010, 10(3); p. 405.

57. Moore, J.W. The End of the Road? Agricultural Revolutions in the Capitalist World-Ecology, 1450-2010. Journal of Agrarian Change 2010, 10(3); p. 147-148.

58. Li, M., Xiao, F. and Zhu, A. Long Waves, Institutional Changes, and Historical Trends: A Study of the Long-Term Movement of the Profit Rate in the Capitalist World-Economy. Journal of WorldSystems Research 2007, XIII(1), 33-54.

59. Liodakis, G. Totalitarian Capitalism and Beyond; Ashgate Publishing: Surrey, UK, 2010.

60. Liodakis, G. Transformation and Crisis of World Capitalism: Long-run Trends and Prospects. Presented at the Conference Political Economy and the Outlook for Capitalism, Paris, July 5-7, 2012. (http://www.assoeconomiepolitique.org/political-economy-outlook-for-capitalism/)

61. Roberts, M. A world rate of profit. Presented at the Conference Political Economy and the Outlook for Capitalism, Paris, July 5-7, 2012. (http://www.assoeconomiepolitique.org/political-economyoutlook-for-capitalism/)

62. Marx, K. Grundrisse; Vintage Books: New York, USA, 1973; p. 704-706.

63. Liodakis, G. Political Economy, Capitalism and Sustainable Development. Sustainability 2010, 2, 2601-2616. (www.mdpi.com/2071-1050/2/8/2601/pdf) 
64. Liodakis, G. The People - Nature Relation and the Historical Significance of the Labour Theory of Value. Capital \& Class 2001, No 73.

65. Cited in [21], 98.

(C) 2011 by the authors; licensee MDPI, Basel, Switzerland. This article is an open access article distributed under the terms and conditions of the Creative Commons Attribution license (http://creativecommons.org/licenses/by/3.0/). 